\title{
Design and Fabrication of High Performance Photoanode of Fe2(Mo04)3/RGO Hybrid Composites For Triiodide Reduction in Dye- Sensitized Solar Cells
}

\section{Selvam Thulasi \\ University College of Engineering \\ Veeranan Arunprasad}

Theni Kammavar Sangam College of Technology

SIVA KARTHIK ( $\sim$ psivakarthick@yahoo.com)

University College of Engineering, Panruti https://orcid.org/0000-0001-8193-1875

G. Elatharasan

University College of Engineering

P. Senthil

Mohammed Sathak Polytechnic College

\section{Original Research}

Keywords: Fe2(MoO4)3, RGO, High surface area, Photo-conversion, Electron-hole separation, Dye sensitized solar cells

Posted Date: February 10th, 2021

DOI: https://doi.org/10.21203/rs.3.rs-173214/v1

License: (c) (i) This work is licensed under a Creative Commons Attribution 4.0 International License.

Read Full License

Version of Record: A version of this preprint was published at Journal of Cluster Science on January 30th, 2022. See the published version at https://doi.org/10.1007/s10876-021-02216-z. 


\section{Abstract}

Discovery of electrode materials with superior light harvesting performance with high conductivity nature have become more and more urgent for the field of photovoltaics and portable electronic devices. Here in, synthesis of $\mathrm{Fe}_{2}\left(\mathrm{MoO}_{4}\right)_{3}$ /reduced graphene oxide (RGO) nanocomposite was prepared by simple hydrothermal approach and used as high efficient dye sensitized solar cells (DSSCs). The decoration of RGO into the $\mathrm{Fe}_{2}\left(\mathrm{MoO}_{4}\right)_{3}$ was proved by various physic-chemical studies such as XRD, SEM, TEM, Raman, UV, PL and BET analysis. Due to the synergic effect between the $\mathrm{Fe}_{2}\left(\mathrm{MoO}_{4}\right)_{3}$ and RGO the light absorption property is significantly improved as well the high surface area $\left(112.5 \mathrm{~m}^{2} / \mathrm{g}\right)$ and pore size $(38.7 \mathrm{~nm})$ was achieved than compared with bare $\mathrm{Fe}_{2}\left(\mathrm{MoO}_{4}\right)_{3}\left(88.5 \mathrm{~m}^{2} / \mathrm{g}\right.$ and $\left.17.8 \mathrm{~nm}\right)$. The $\mathrm{Fe}_{2}\left(\mathrm{MoO}_{4}\right)_{3} / \mathrm{RGO}$ hybrid photoanode establish to display an outstanding catalytic activity toward the reduction of triiodide to iodide in a dye-sensitized solar cell (DSSC) and can provide a solar cell efficiency of $9.65 \%$, which is superior to a Pt-based DSSC (6.17\%). The better electro-catalytic ability of $\mathrm{Fe}_{2}\left(\mathrm{MoO}_{4}\right)_{3} / \mathrm{RGO}$ electrode is obtained by a synergistic effect that resulted in the high specific surface area and intrinsic reactivity of the photocathode materials.

\section{Introduction}

Significant attempts have been made by the so-called third generation from the last two decades. Solar cell production provided by dye-sensitized solar cells because of another type of solar cell provide compatible with versatile substrates, low cost, ease of manufactory and frequently use. High photo-to-electron conversion efficiency that enables them to interact with fossils electrical generation of fuel [1-5]. The most major move in the manufacture of DSSCs has to be taken to making the highefficiency photoelectrode materials in charge carrier insertion and established photo - catalytic stability in electrolytes where redox is severe response may have taken place. Titanium dioxide $\left(\mathrm{TiO}_{2}\right)$ was commonly considered to be fine photoanode content with excellent analytical stability. However, $\mathrm{TiO}_{2}$ does have a broad band gap of $\sim 3.0 \mathrm{eV}$ and can therefore only be photo-excited by UV light $(<400 \mathrm{~nm})$. In wavelength, this is only $5 \%$ of solar light in percentage of energy [6-10]. As a result, materials that show a narrower photo-response to the spectral light are strongly recommended to increase energy conversion efficiency, even though photo absorption was partially caused by enzyme inhibitor dye molecules. Functional materials have received tremendous attention to date because of their attractive features. Functional materials with an inherent feature, charge carrying ability, specific chemical and physical attributes are provided special properties vs. bulk alternative [11-14]. Recently, molybdate of $\mathrm{AMoO}_{4}$ forms ( $\mathrm{A}=\mathrm{Zn}, \mathrm{Mn}, \mathrm{Co}, \mathrm{Cu}, \mathrm{Cd}, \mathrm{Ni}, \mathrm{Ba}$ ) of nanostutures were designed and synthesized using the hydrothermal process and systematically examined their electrochemical, luminescence and photocatalytic ability in the view of practical device applications [15-18].

Among them, Iron molybdate $\left(\mathrm{Fe}_{2}\left(\mathrm{MoO}_{4}\right)_{3}\right)$, an important metal molybdate was generally used as an efficient catalyst due to their outstanding light absorption ability, luminescence properties, chemical stability, economy, non-toxic of iron and its open three dimensions framework. It also been widely used in 
different fields of applications such as, photocatalyst, solar cell, optoelectronic devices, alloys preparation, gas sensors and lithium ion batteries [19-24]. Conversely its weak cycloability and low electrical conductivity restrict its further use. Graphene is a broad monolayer sheet of sp2 carbon bound with special optical, electrical, physical and electronic properties. Graphen oxide (defined as a thin layer of graphite oxide) is the most significant chemical reduction graphene. Reduced graphene oxide (RGO) has a high surface to volume ratio and strong electronic charge transport, which are supposed to promote transient electrochemistry. Herein we reported the high performance PCE based $\mathrm{Fe}_{2}\left(\mathrm{MoO}_{4}\right)_{3} / \mathrm{RGO}$ DSSC electrode by facile hydrothermal route. The $\mathrm{Fe}_{2}\left(\mathrm{MoO}_{4}\right)_{3} / \mathrm{RGO}$ hybrid photoanode establish to display an outstanding catalytic activity toward the reduction of triiodide to iodide in a dyesensitized solar cell (DSSC) and can provide a solar cell efficiency of $9.65 \%$, which is superior to a Ptbased DSSC (6.17\%). The better electro-catalytic ability of $\mathrm{Fe}_{2}\left(\mathrm{MoO}_{4}\right)_{3} / \mathrm{RGO}$ electrode is obtained by a synergistic effect that resulted in the high specific surface area and intrinsic reactivity of the photocathode materials.

\section{Experimental Procedure}

\subsection{Materials}

All chemicals used, were of analytical grade, $\mathrm{Fe}\left(\mathrm{NO}_{3}\right)_{3} \cdot 9 \mathrm{H}_{2} \mathrm{O},\left(\mathrm{NH}_{4}\right)_{6} \mathrm{Mo}_{7} \mathrm{O}_{24} \cdot 4 \mathrm{H}_{2} \mathrm{O}$, graphite powder purchased from Dae-Jung Korea. $\mathrm{NaOH}$ and ethanol was obtained from Merck chemicals.

\subsection{Synthesis of $\mathrm{Fe}_{2}\left(\mathrm{MoO}_{4}\right)_{3} / \mathrm{RGO}$ composite samples}

Modified hummers method [25] has been used to prepare the graphene oxide from graphite powders. A proper amount of $\mathrm{Fe}\left(\mathrm{NO}_{3}\right)_{3} \cdot 9 \mathrm{H}_{2} \mathrm{O}$ and $\left(\mathrm{NH}_{4}\right)_{6} \mathrm{Mo}_{7} \mathrm{O}_{24} \cdot 4 \mathrm{H}_{2} \mathrm{O}$ was mixed with $50 \mathrm{ml}$ of Milli-Q water and mixed completely. A various weight percentage of $\mathrm{GO}(1,2$ and $5 \%)$ was mixed with the above solution and ultrasonically dispersed for $30 \mathrm{~min}$. Then the $\mathrm{pH}$ of the solution was adjusted by adding $\mathrm{NaOH}$ drop wise under mild stirring. Then hydrothermal reaction was adapted to synthesis of photoanode [26]. The samples with various ratio of GO (1, 2 and 5\%)) was named as FMG1, FMG2 and FMG5, accordingly.

\section{Results And Discussion}

\subsection{Structural properties}

The XRD spectra of the crystalline orientation of the RGO, $\mathrm{Fe}_{2}\left(\mathrm{MoO}_{4}\right)$ and $\mathrm{Fe}_{2}\left(\mathrm{MoO}_{4}\right)_{3} / \mathrm{RGO}$ composites are shown as shown in Fig.1. It can be seen that $\mathrm{GO}$ shows an extreme diffraction peak at $2 \theta$ of $10.75^{\circ}$ attributed to (002) the $\mathrm{GO}$ plane, which emerges from graphite via the Hummers process. Well crystalline with sharp diffraction peaks were found in the pure $\mathrm{Fe}_{2}\left(\mathrm{MoO}_{4}\right)_{3}$, the peaks are correlate with monoclinic phase of monoclinic crystal phase of $\mathrm{Fe}_{2}\left(\mathrm{MoO}_{4}\right)_{3}$ (JCPDS 31-0642). Both GO and $\mathrm{Fe}_{2}\left(\mathrm{MoO}_{4}\right)_{3}$ diffractions were could be found in all the composite samples. Moreover, when the content of RGO increases the diffraction intensity of $\mathrm{Fe}_{2}\left(\mathrm{MoO}_{4}\right)_{3}$ was sharpened while the intensity of RGO peaks could 
be decreased. The results suggest that the incorporated RGO significantly improve the crystalline nature of $\mathrm{Fe}_{2}\left(\mathrm{MoO}_{4}\right)_{3}$. The structural details of the samples were further examined by Raman analysis and the correlated spectrum is shown in Figure 2. As seen in the figure 2, the Raman peaks at 980, 812

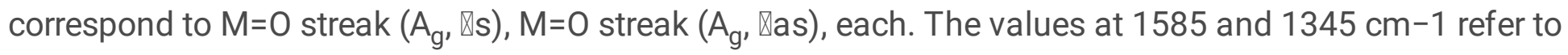
the $\mathrm{G}$-band ( $\mathrm{E}_{2 \mathrm{~g}}$ symmetry, in-plane bond-stretching motion of pairs of $\mathrm{sp}^{2} \mathrm{C}$ atoms) and the $\mathrm{D}$-band (defect-related) of the graphene sheet [27]. The typical characteristic peaks of $\mathrm{Fe}_{2}\left(\mathrm{MoO}_{4}\right)_{3}$ and $\mathrm{RGO}$ occur simultaneously, leading to the formation of $\mathrm{Fe}_{2}\left(\mathrm{MoO}_{4}\right)_{3} / \mathrm{RGO}$ nanocomposite.

\subsection{Morphological analysis}

To evaluate the responsibility of $\mathrm{GO}$ scaffold in $\mathrm{Fe}_{2}\left(\mathrm{MoO}_{4}\right)_{3} / \mathrm{RGO}$ composites, SEM and TEM images were taken. Figure 3 (a-c) shows the SEM images of bare RGO, $\mathrm{Fe}_{2}\left(\mathrm{MoO}_{4}\right)_{3}$ and $\mathrm{Fe}_{2}\left(\mathrm{MoO}_{4}\right)_{3} / \mathrm{RGO}$ (FMG5) samples, respectively. SEM image of bare RGO (Fig. 3a) shows decreased thickness with the surface scrunched up, which is advantageous to the deformation of other metal oxides. Perfectly obvious with integrated spherical shaped nanoparticles are found in pristine $\mathrm{Fe}_{2}\left(\mathrm{MoO}_{4}\right)_{3}$ nanoparticles (Fig. 3a), which are consistently covered on the RGO sheet surface (Fig. 3c). The distribution of $\mathrm{Fe}_{2}\left(\mathrm{MoO}_{4}\right)_{3} \mathrm{NPs}$ over all the surface of the RGO was further inveterate via high magnification TEM picture, as shown in Fig 3 (d-f). The images reveal that neither of them surfaced NPs or isolated NPs outside of the RGO nanosheets have been found. Implied that the rapid expansion of ultrafine $\mathrm{Fe}_{2}\left(\mathrm{MoO}_{4}\right)_{3} \mathrm{NPs}$ existed only on the GO surface. To confirm the stoichiometry of these samples, we mapped the elemental distribution of $\mathrm{Fe}, \mathrm{Mo}$, $\mathrm{C}$ and $\mathrm{O}$ on the surface of samples and the relevant images are shown in Fig. 3 (g-j). The elemental mapping clearly shows that the RGO was successfully incorporated in $\mathrm{Fe}_{2}\left(\mathrm{MoO}_{4}\right)_{3}$.

\subsection{Optical properties}

UV-Vis DRS was further explored to investigate the optical characteristics of the photoanode materials. Figure 4a) shows the absorption spectra of all the photoanode samples. The absorption of pure sample lies in the visible light region $(\sim 485 \mathrm{~nm})$. Further the extended absorption in the red shift wavelength was noticed after loading the RGO content. The K-M plot [28-30] is used to estimate the optical band gap. The band gap energy of pure $\mathrm{Fe}_{2}\left(\mathrm{MoO}_{4}\right)_{3}, \mathrm{FMG1}, \mathrm{FMG} 2$ and FMG5 are 2.55, 2.47, 2.35 and $2.25 \mathrm{eV}$, respectively (Fig. 4b). With the aim of studying the coupling photo-induced electron-hole pairing mechanisms, Photoluminescence $(\mathrm{PL})$ spectral analysis is often used and the resultant spectrum is shown in Figure 5. A clear emission band appeared around at $480 \mathrm{~nm}$ for all the photoanodes. Remarkably, the intensity emission was gradually decreased when the loading amount of RGO is increases, which suggesting that photo-generated electron-hole recombination system was suppressed due to the solid electron transfers potential of RGO.

\subsection{Textural and elemental composition analysis}

Brunauer-Emmett-Teller adsorption/desorption of the liquid nitrogen technique is used to explore the surface area and size of pore values. The isotherm was taken for $\mathrm{Fe}_{2}\left(\mathrm{MoO}_{4}\right)$ and $\mathrm{Fe}_{2}\left(\mathrm{MoO}_{4}\right)_{3} / \mathrm{RGO}$ 
(FMG5) samples and the pertinent plot is shown in Figure 6 a). Both the samples exhibit the IV type adsorption isotherm, complemented by $\mathrm{H} 3$ hysteresis. This characteristics nature resembles that mesoporous of the materials [31-33]. Due to the synergic effect between the $\mathrm{Fe}_{2}\left(\mathrm{MoO}_{4}\right)_{3}$ and RGO the light absorption property is significantly improved as well the high surface area $\left(112.5 \mathrm{~m}^{2} / \mathrm{g}\right)$ and pore size $(38.7 \mathrm{~nm})$ was achieved than compared with bare $\mathrm{Fe}_{2}\left(\mathrm{MoO}_{4}\right)_{3}\left(88.5 \mathrm{~m}^{2} / \mathrm{g}\right.$ and $\left.17.8 \mathrm{~nm}\right)$. Chemical state of the samples was further elucidating by XPS analysis. Figure 7a) shows the XPS survey spectrum of $\mathrm{Fe}_{2}\left(\mathrm{MoO}_{4}\right)_{3} / \mathrm{RGO}$ (FMG5) samples, which is rendering the key elements of $\mathrm{Fe} 2 \mathrm{p}$, Mo 3d, 01s and C1s. The Fe $2 p_{1 / 2}$ and $2 p_{3 / 2}$ states were presented at 724.1 and $711.1 \mathrm{eV}$, respectively (Fig. $7 \mathrm{~b}$ ). While the two binding energies were positioned at 235.5 and $232.4 \mathrm{eV}$, corresponding to the Mo $3 \mathrm{~d}_{3 / 2}$ and Mo $3 \mathrm{~d}_{5 / 2}$, accordingly (Fig. 7c). The 0 1s state of the composite was found with equivalent binding energy of 530.1 eV (Fig. 7d). Core scale of binding $C$ 1s energies of the spectrum shown in Figure 7(e) could be the visible peaks at $284.5 \mathrm{eV}$ and $288.6 \mathrm{eV}$, respectively. This could be due to the characteristic sp ${ }^{2}$ hybridized graphite-like aromatic rings of RGO and atoms exist.

\subsection{Photovoltaic studies}

DSSC performance was evaluated for the constructed sandwich type device, which is shown in Figure 8a). The detailed setup with description was also mentioned in detail for our previous published work [35]. The current $(\mathrm{J})$ - voltage $(\mathrm{V})$ characteristics of the DSSC was monitored under sun illumination (1.5 AM) conditions for each of these electrodes (Fig. 8b) and the results are summarized in Table 1. The results reveal that $\mathrm{Fe}_{2}\left(\mathrm{MoO}_{4}\right)_{3} / \mathrm{RGO}$ (FMG5) photoanode show high PCE of $9.65 \%$ due to the higher current density (20.98). While the PCE value of pure Pt, $\mathrm{Fe}_{2}\left(\mathrm{MoO}_{4}\right)_{3}, \mathrm{FMG} 1$ and FMG3 are 6.17, 4.33, 6.89 and $7.35 \%$. Due to the high reduction of triiodide and electrical conductivity by RGO, the PCE is significantly improved for the composite electrode. Incident photon-to-current conversion efficiency (IPCE) was further carried out to know the role of RGO on the performance of the DSSC and the relevant plot is shown in 8c). The IPCE values are clearly observed in the wavelength between $400-700 \mathrm{~nm}$, which is characteristics behavior of N17 dye. The FMG3 photoanode shows high IPCE value of $87 \%$ than compared with other photoanode materials such as $\mathrm{Fe}_{2}\left(\mathrm{MoO}_{4}\right)_{3},(41 \%) \mathrm{FMG} 1$ (54\%) and FMG3 (67\%). The high stability of the device was further confirmed through multiple experiments of the J-V plot. The device was evaluated over 60 day with regular interval of 10 day. The device loss only $2.3 \%$ of PCE value from its initial value. In addition, electrochemical impedance spectra (EIS) were tested to know the catalytic skill of the electrode samples. Figure 9a) shows the Nquist plot of the electrodes with equivalent circuit (inset). The semicircle evidently illustrate that smaller Rs $(5.4 \Omega)$ and Rct (12.5 $\Omega$ ) value of $\mathrm{Fe}_{2}\left(\mathrm{MoO}_{4}\right)_{3} / \mathrm{RGO}$ (FMG5) photoanode than other samples. The factors obtained from EIS was also depicts in Table 2. Moreover, the FMG photoanode has high electron life time (78 ns), which is caused by the good electrocatalytic activity to reduction in the triiodide. The photovoltaic mechanism of the proposed work is shown in Figure $9 \mathrm{~b})$. The $\mathrm{Fe}_{2}\left(\mathrm{MoO}_{4}\right)_{3}$ nanoparticles are anchored to the RGO, which results in excited electrons are generated without impediment. The electrons obtained can be exported 
from $\mathrm{Fe}_{2}\left(\mathrm{MoO}_{4}\right)_{3}$. Hence, the conductive layer was effectively prevented by RGO bridges and therefore the recombination of electron-hole pair is effectively prevented.

\section{Conclusions}

The present study provides an example of RGO incorporated molybdate hybrid structure as photoanode materials for high performance DSSCs. The $\mathrm{Fe}_{2}\left(\mathrm{MoO}_{4}\right)_{3} / \mathrm{RGO}$ hybrid photoanode establish to display an outstanding catalytic activity toward the reduction of triiodide to iodide in a dye-sensitized solar cell (DSSC) and can provide a solar cell efficiency of $9.65 \%$, which is superior to a Pt-based DSSC $(6.17 \%)$. The semicircle evidently illustrate that smaller Rs $(5.4 \Omega)$ and Rct $(12.5 \Omega)$ value of $\mathrm{Fe}_{2}\left(\mathrm{MoO}_{4}\right)_{3} / \mathrm{RGO}$ (FMG5) photoanode than other samples. This outcome again features the fact that surface interactions of RGO and Iron molybdate play a key role in the electro catalytic activity, and appropriate regulation of these interactions can be used to maximise to developing new, effective photoanodes in the applications of DSSCs.

\section{References}

1. I. Ahmad, U. Khan, Y.K. Gun.ko, Graphene, carbon nanotube and ionic liquid mixtures: towards new quasi-solid state electrolytes for dye sensitised solar cells, J. Mater. Chem. 21 (2011) 16990-16996.

2. S. Ahmad, E. Guillén, L. Kavan, M. Grätzel, M.K. Nazeeruddin, Metal free sensitizer and catalyst for dye sensitized solar cells, Energy Environ. Sci. 6 (2013) 3439-3466

3. Y. Chiba, A. Islam, Y. Watanabe, R. Komiya, N.Koide, Dye-Sensitized Solar Cells with Conversion Efficiency of 11.1\%, Jpn. J. Appl. Phys. Part 2, 45 (2006) 24-28.

4. M.K. Nazeeruddin, P. Pechy, M. Grätzel, Efficient panchromatic sensitization of nanocrystalline $\mathrm{TiO}_{2}$ films by a black dye based on a trithiocyanato-ruthenium complex, Chem. Commun. 18 (1997) 1705-1706.

5. M. Grätzel, Photoelectrochemical cells, Nature. 414 (2001) 338-344.

6. Y. Wu, J. Zhang, L. Xiao and F. Chen, Properties of carbon and iron modified $\mathrm{TiO}_{2}$ photocatalyst synthesized at low temperature and photodegradation of acid orange 7 under visible light, Appl. Surf. Sci, 256 (2010) 4260-4268.

7. Y. Haldorai, A. Rengaraj, C.H. Kwak, Y.S. Huh and Y.-K. Han, Fabrication of nano TiO $2 @ g r a p h e n e$ composite: reusable photocatalyst for hydrogen production, degradation of organic and inorganic pollutants, Synth. Met. 198 (2014) 10-18.

8. W. Fan, Q. Lai, Q. Zhang and Y. Wang, Nanocomposites of $\mathrm{TiO}_{2}$ and reduced graphene oxide as efficient photocatalysts for hydrogen evolution, J. Phys. Chem. C. 115 (2011) 10694-10701.

9. A.A. Ismail, R.A.Geioushy, Houcine Bouzi d, Saleh A.Al-Sayari, AliAl-Hajry, Detlef W.Bahnemann, $\mathrm{TiO}_{2}$ decoration of graphene layers for highly efficient photocatalyst: impact of calcination at different gas atmosphere on photocatalytic efficiency, Appl. Catal. B Environ. 129 (2013) 62-70. 
10. R. Raja, M. Govindaraj, M.D. Antony, K. Krishnan, V. Eswaramoorthi, A. Sambandam et Effect of $\mathrm{TiO}_{2}$ /reduced graphene oxide composite thin film as a blocking layer on the efficiency of dyesensitized solar cells, J. Solid State Electrochem, 21 (2017) 891-903.

11. K. Qureshi, M.Z. Ahmad, I.A. Bhatti, M. Zahid, J. Nisar, M. Iqbal, Graphene oxide Decorated $\mathrm{ZnWO}_{4}$ architecture synthesis, characterization and photocatalytic activity evaluation, J. Mol. Liq. 285 (2019) 778-789.

12. M. Arshad, A. Qayyum, G. Abbas, R. Haider, M. Iqbal, A. Nazir, Influence of different solvents on portrayal and photocatalytic activity of tin-doped zinc oxide nanoparticles, Mol. Liq. 260 (2018) 272278.

13. M. Irandost, R. Akbarzadeh, M. Pirsaheb, A. Asadi, P. Mohammadi, M. Sillanpää, Fabrication of highly visible active N, S co-doped $\mathrm{TiO}_{2} @ \mathrm{MoS}_{2}$ heterojunction with Synergistic effect for photocatalytic degradation of diclofenac: mechanisms, modeling and degradation pathway, J. Mol. Liq. 291 (2019), 111342.

14. J. Mishra, D.S. Pattanayak, A.A. Das, D.K. Mishra, D. Rath, N.K. Sahoo, Enhanced Photocatalytic degradation of cyanide employing Fe-porphyrin sensitizer with Hydroxyapatite palladium doped $\mathrm{TiO}_{2}$ nano-composite system, J. Mol. Liq. 287 (2019), 110821.

15. W. Xiao, J.S. Chen, C.M. Li, R. Xu, X.W. Lou, Synthesis, characterization, and lithium storage capability of $\mathrm{AMoO}_{4}(\mathrm{~A}=\mathrm{Ni}, \mathrm{Co})$ nanorods, Chem. Mater. 22 (2009) 746-754.

16. P. Gao, Y. Xie, L. Ye, Y. Chen, Z. Li, Synthesis of single-crystal $\mathrm{BaMo}_{2} \mathrm{O}_{7}$ nanowire bundles:a general, low-temperature hydrothermal approach to 1 Dmolybdenumoxide based nanostructures, Chem. Lett. 35 (2005) 162-163.

17. R. Packiaraj, P. Devendran, K. Venkatesh, A. Manikandan, N. Nallamuthu, Electrochemical investigations of magnetic $\mathrm{CO}_{3} \mathrm{O}_{4}$ nanoparticles as an active electrode for supercapacitor applications, J. Superconduct. Novel Magnet. 32 (2019) 2427-2436.

18. K. Seevakan, A. Manikandan, P. Devendran, A. Baykal, T. Alagesan, Electrochemical and magnetooptical properties of cobalt molybdate nano-catalyst as high performance supercapacitor, Ceram. Int. 44 (2018) 17735-17742.

19. H. Veisi, J. Gholami, H. Ueda, P. Mohammad, M. Noroozi, Magnetically palladium catalyst stabilized by diaminoglyoxime-functionalized magnetic $\mathrm{Fe}_{3} \mathrm{O}_{4}$ nanoparticles as active and reusable catalyst for Suzuki coupling reactions, J. Mol. Catal. A 396 (2015) 216-223.

20. K. Otsuka, Y. Wang, I. Yamanaka, A. Morikawa, Kinetic study of the partialoxidation of methane over $\mathrm{Fe}_{2}\left(\mathrm{MoO}_{4}\right)_{3}$ catalyst, J. Chem. Soc. Faraday Trans. 89 (1993) 4225-4230.

21. E. Tronconi, P. Forzatti, J. Martin, S. Mallogi, Selective catalytic removal of NOx: A mathematical model for design of catalyst and reactor, Chem. Eng. Sci. 47 (1992) 2401-2406.

22. H. Jung, J. Hassoun, J. Park, Y. Sun, B. Scrosati, An improved high-performance lithium-air battery, Nature 4 (2012) 579-585. 
23. C. Gao, Z. Lin, N. Li, P. Fu, X. Wang, Preparation and $\mathrm{H}_{2} \mathrm{~S}$ gas-sensing performances of coral-like $\mathrm{SnO}_{2}-\mathrm{CuO}$ nanocomposite, Acta Metall. Sin.-Engl. 28 (2015) 1190-1197.

24. A. Chychko, L. Teng, M. Nzotta, S. Seetharaman, Synthesis and characterization of $\mathrm{Fe}_{2} \mathrm{MoO}_{4}$ as a precursor material for Mo alloying in steel, Steel Res. Int. 82 (2011) 269-276.

25. W. Fan, Q. Lai, Q. Zhang and Y. Wang, Nanocomposites of $\mathrm{TiO}_{2}$ and reduced graphene oxide as efficient photocatalysts for hydrogen evolution, J. Phys. Chem. C. 115 (2011). 10694-10701.

26. Xintong Liu, Youyi Zhu, Wenjun Li, Fangzhi Wang, Hongda Li, Chaojun Ren, Yanjun Zhao, Modified surficial chemistry micro-circumstance and mid-gap effect on photocatalytic ability of tetracycline by introducing of nitrogen in $\mathrm{Fe}_{2}\left(\mathrm{MoO}_{4}\right)_{3}$, Molecular Catalysis, 434 (2017) 106-115

27. Y. H. Jung, C. H. Lim and D. K. Kim, Graphene-supported $\mathrm{Na}_{3} \mathrm{~V}_{2}\left(\mathrm{PO}_{4}\right)_{3}$ as a high rate cathode material for sodium-ion batteries, J. Mater. Chem. A, 1 (2013) 11350-11354.

28. M. Parthibavarman, S. Sathishkumar, S. Prabhakaran, Enhanced visible light photocatalytic activity of tin oxide nanoparticles synthesized by different microwave optimum conditions Mater. Sci. Mater. Electron. 29 (2018) 2341-2350

29. M. Parthibavarman, S. Sathishkumar, S. Prabhakaran, M. Jayashree, R. BoopathiRaja, High visible light-driven photocatalytic activity of large surface area $\mathrm{Cu}$ doped $\mathrm{SnO} 2$ nanorods synthesized by novel one-step microwave irradiation method, Journal of the Iranian Chemical Society 15 (2018) 2789-2801.

30. M. Parthibavarman, K. Vallalperuman, S. Sathishkumar, M. Durairaj, K. Thavamani, A novel microwave synthesis of nanocrystalline $\mathrm{SnO}_{2}$ and its structural optical and dielectric properties, $\mathrm{J}$. Mater. Sci. Mater. Electron. 25 (2014) 730-735.

31. M. Parthibavarman, M. Karthik, P. Sathishkumar, R. Poonguzhali, Rapid synthesis of novel Cr-doped $\mathrm{WO}_{3}$ nanorods: an efficient electrochemical and photocatalytic performance, Iran. Chem. Soc. 15 (2018) 1419-1430.

32. R. BoopathiRaja, M. Parthibavarman, Hetero-structure arrays of $\mathrm{MnCo}_{2} \mathrm{O}_{4}$ nanoflakes@ nanowires grown on Ni foam: Design, fabrication and applications in electrochemical energy storage, J. Alloy. Compd. 811 (2019) 152084

33. R. BoopathiRaja, M. Parthibavarman, A. Nishara Begum, Hydrothermal induced novel $\mathrm{CuCO}_{2} \mathrm{O}_{4}$ electrode for high performance supercapacitor applications. Vacuum. 165 (2019) 96-104

34. Xintong Liu, Youyi Zhub, Wenjun Li, Fangzhi Wang, Hongda Li, Chaojun Ren, Yanjun Zhao, Modified surficial chemistry micro-circumstance and mid-gap effect on photocatalytic ability of tetracycline by introducing of nitrogen in $\mathrm{Fe}_{2}\left(\mathrm{MoO}_{4}\right)_{3}$, Molecular Catalysis, 434 (2017) 106-115

35. M. Durairasan, P. SivaKarthik, J. Balaji, B. Rajeshkanna, Design and fabrication of $\mathrm{WSe}_{2} / \mathrm{CNTs}$ hybrid network: A highly efficient and stable electrodes for dye sensitized solar cells (DSSCs), Diamond and Related Materials, 12 (2020) 108174

\section{Tables}


Table.1 Photovoltaic parameters of pure RGO, $\mathrm{Fe}_{2}\left(\mathrm{MoO}_{4}\right)_{3}$ and $\mathrm{Fe}_{2}\left(\mathrm{MoO}_{4}\right)_{3} / \mathrm{RGO}$ composite samples

\begin{tabular}{lccccc}
\hline Parameters & Pt & Fe $_{2}\left(\mathbf{M o O}_{4}\right) \mathbf{3}$ & FMGl & FMG2 & FMG5 \\
\hline Jsc $\left(\mathrm{mA} / \mathrm{cm}^{2}\right)$ & 13.4 & 9.77 & 15.11 & 17.95 & 19.11 \\
Voc $(\mathrm{mV})$ & 660 & 588 & 726 & 819 & 866 \\
Fill Factor & 66.1 & 56.9 & 68.2 & 73.3 & 87.5 \\
Efficiency $\eta(\%)$ & 6.17 & 4.33 & 6.89 & 7.35 & 9.65 \\
\hline
\end{tabular}

Table.2 EIS parameters of pure RGO, $\mathrm{Fe}_{2}\left(\mathrm{MoO}_{4}\right)_{3}$ and $\mathrm{Fe}_{2}\left(\mathrm{MoO}_{4}\right)_{3} / \mathrm{RGO}$ composite samples

\begin{tabular}{llll}
\hline Samples & $\mathbf{R s} / \mathbf{\Omega} \mathbf{c m}^{2}$ & $\mathbf{R c t} / \mathbf{\Omega} \mathbf{c m}^{\mathbf{2}}$ & $\mathbf{r} / \mathbf{n s}$ \\
\hline $\mathrm{Fe}_{2}\left(\mathrm{MoO}_{4}\right)_{3}$ & 12.5 & 75.1 & 27 \\
FMG1 & 10.5 & 62.4 & 32 \\
FMG2 & 8.1 & 38.3 & 45 \\
FMG5 & 5.4 & 17.7 & 78 \\
\hline
\end{tabular}

Figures 


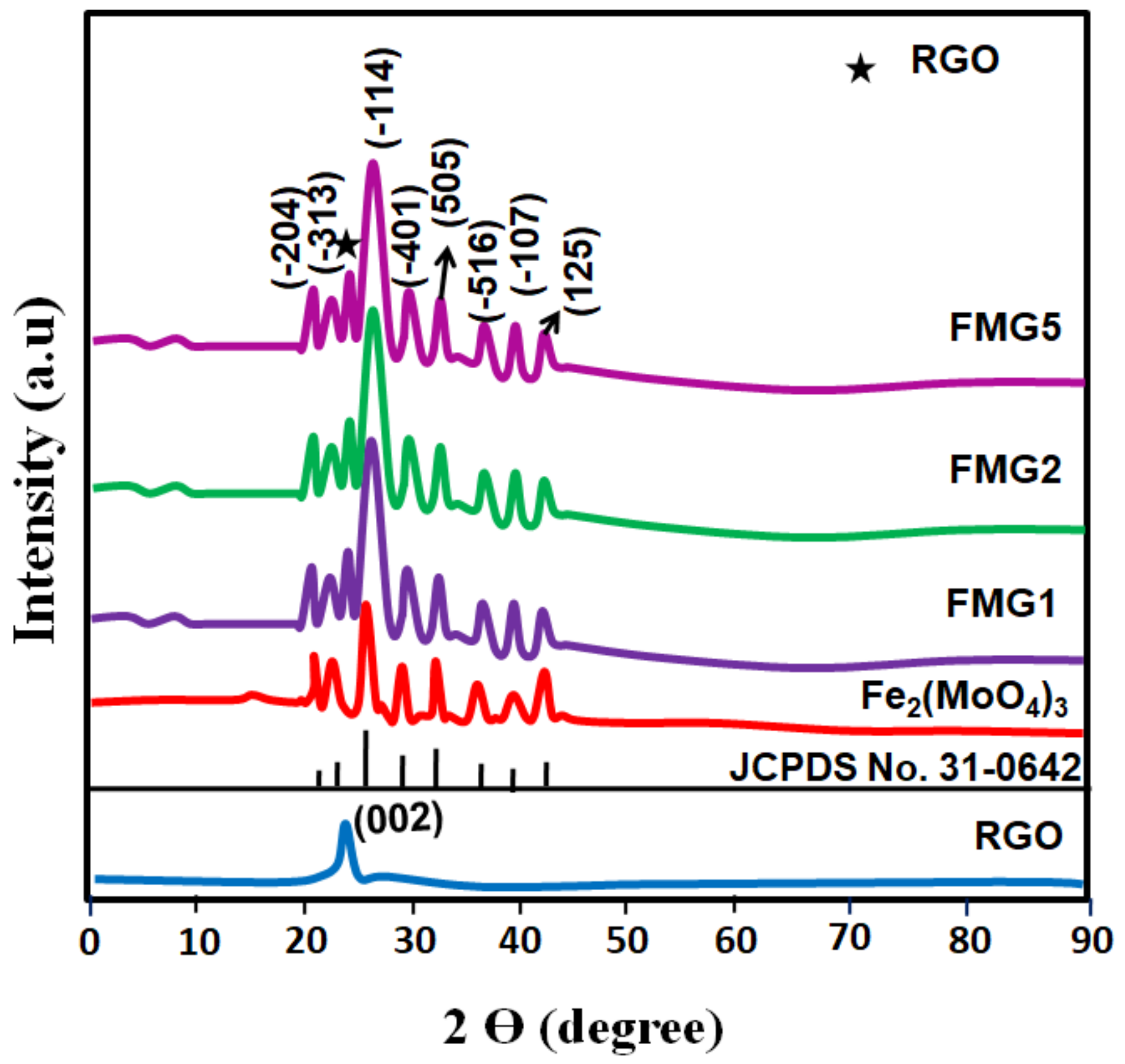

Figure 1

(a) Powder XRD pattern of the samples 


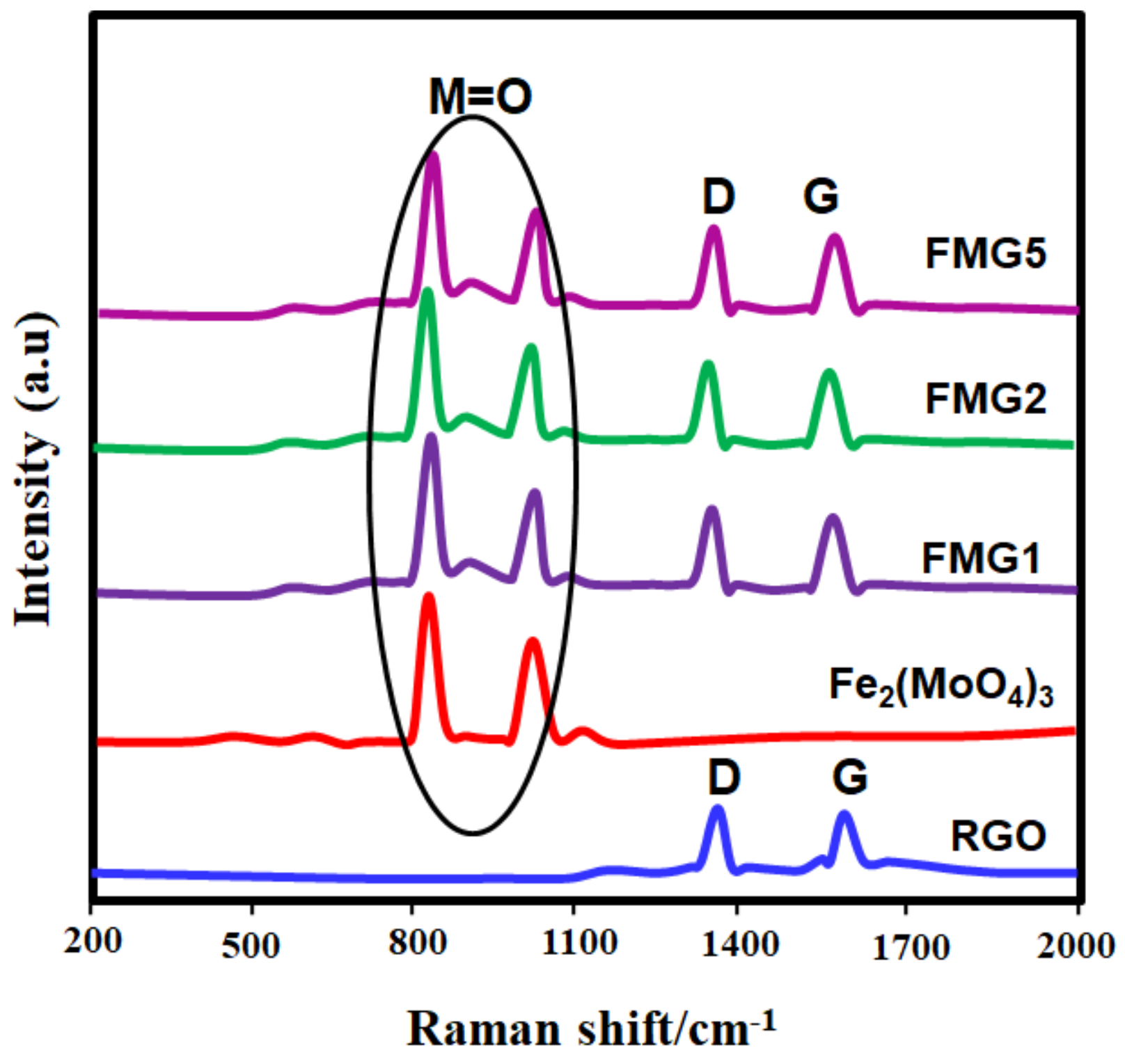

Figure 2

Raman spectra of the samples 


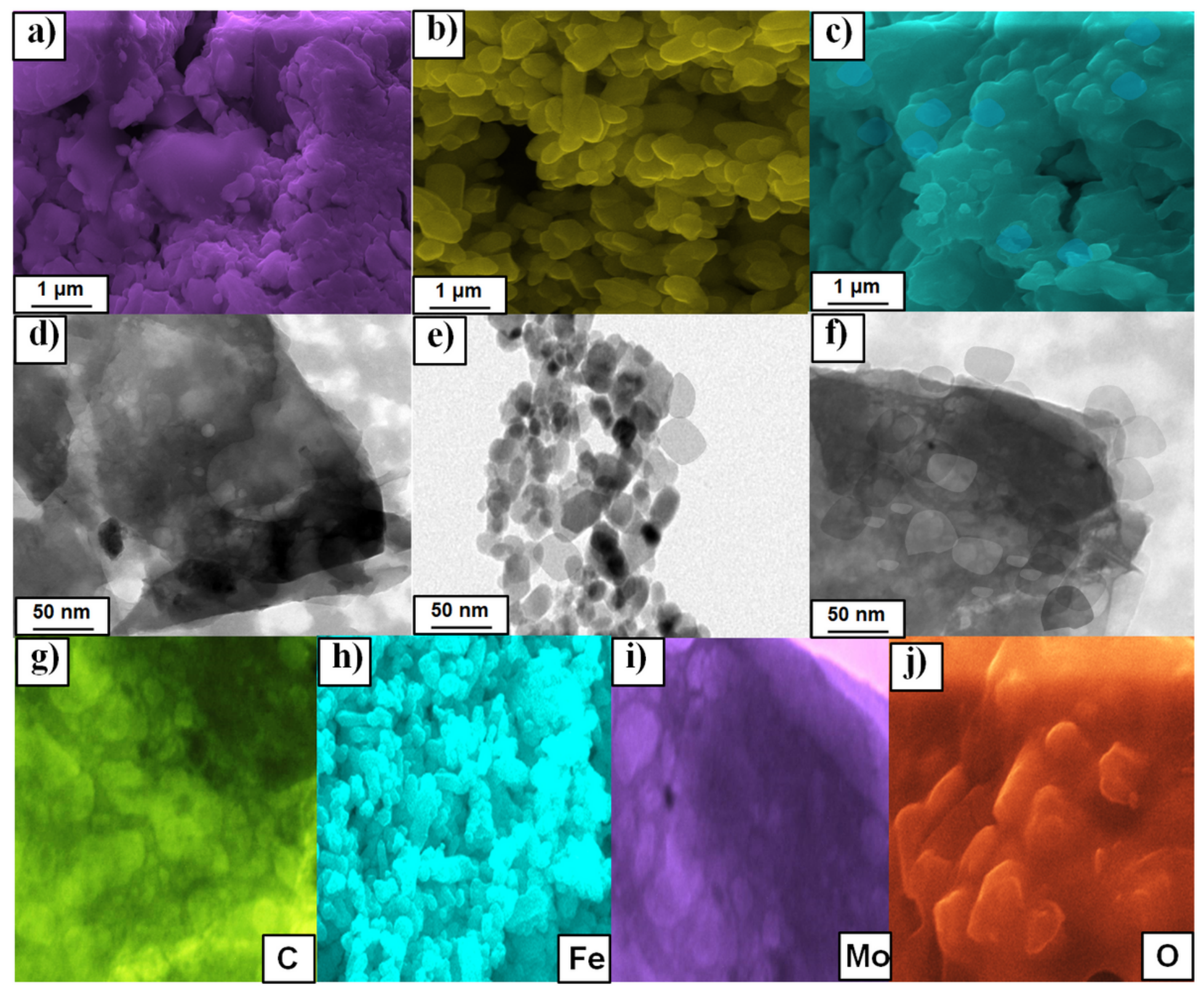

Figure 3

SEM images of (a) RGO; (b) Fe2(MoO4)3; (c) FMG5; TEM images of (d) RGO; (e) Fe2(MoO4)3; (f) FMG5; Elemental mapping of (g) C; (h) Fe; (i) Mo and (j) $\mathrm{O}$ 


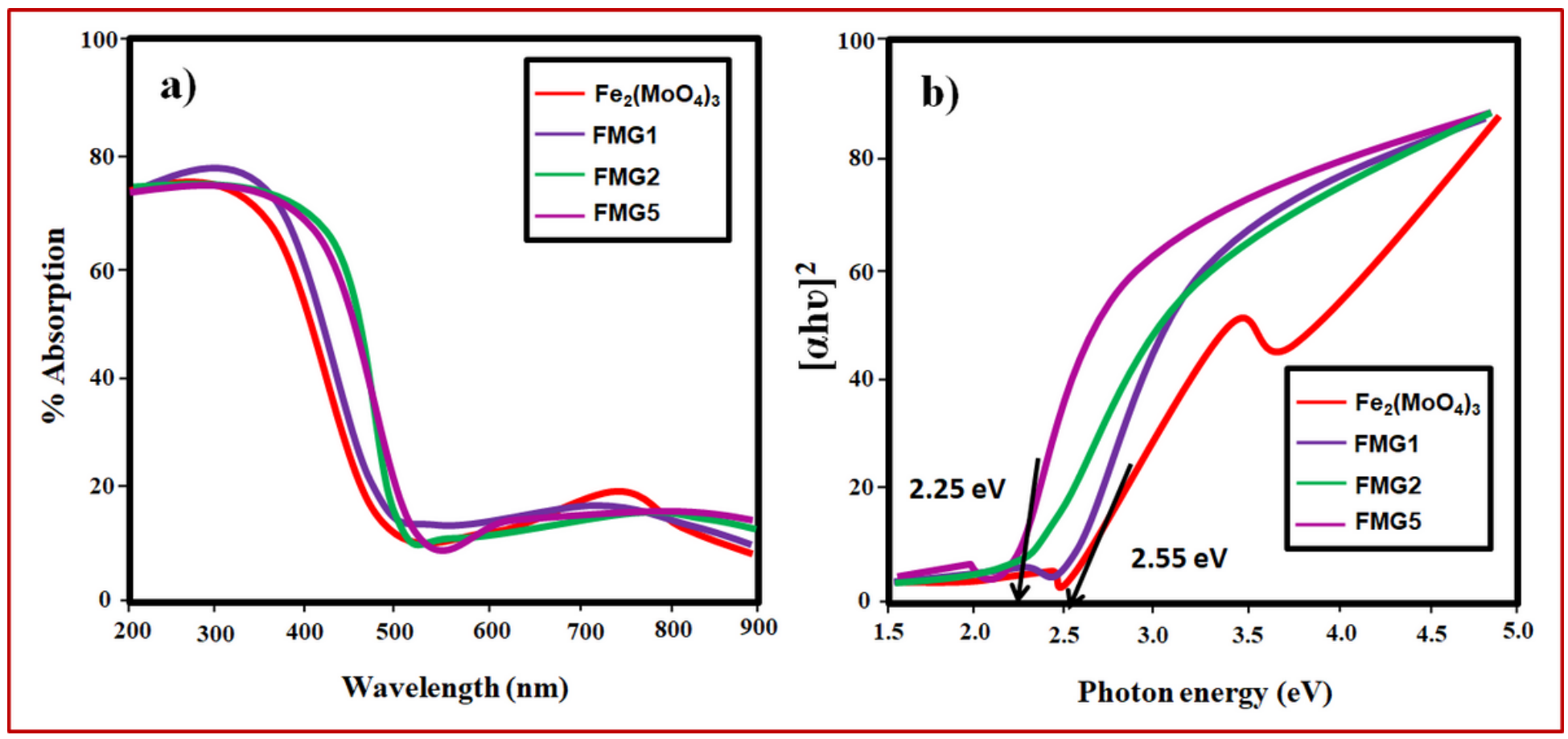

Figure 4

(a) UV-Vis absorption spectra of the electrode samples and b) band gap plot 


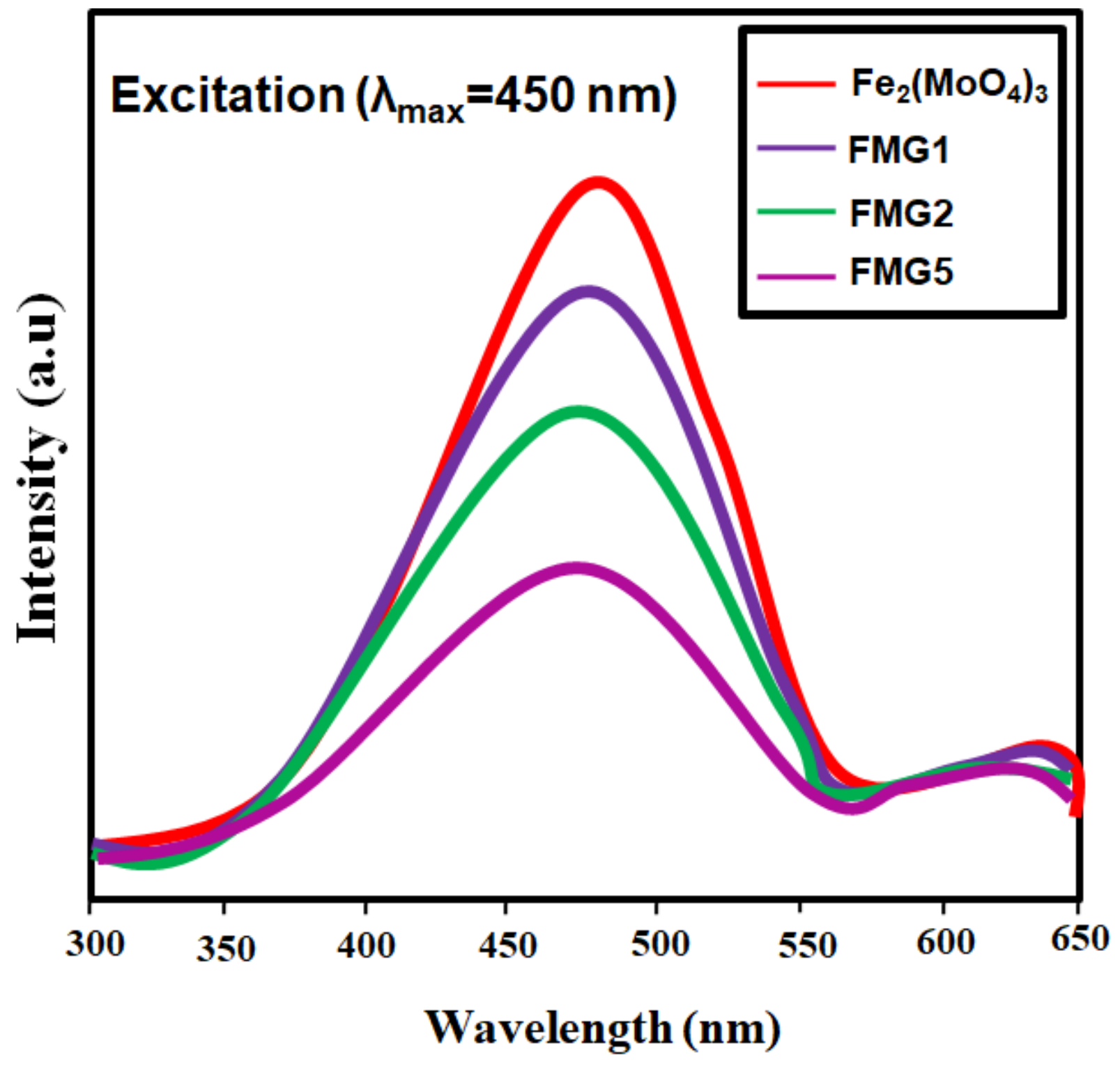

Figure 5

(a) Photoluminescence spectra of the electrode samples 


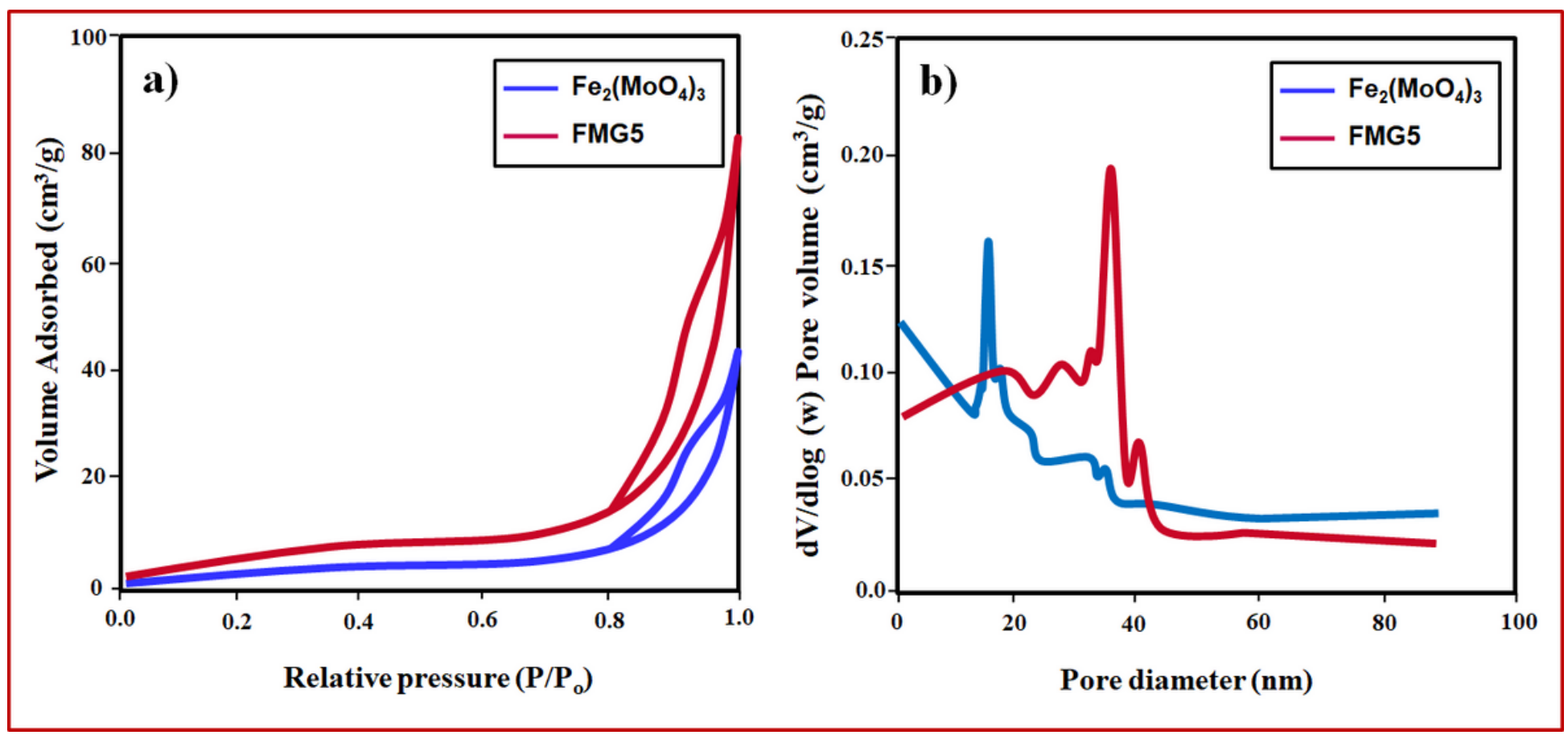

Figure 6

(a) N2 adsorption and desorption analysis Fe2(MoO4)3 and FMG5samples (b) corresponding pore size distribution
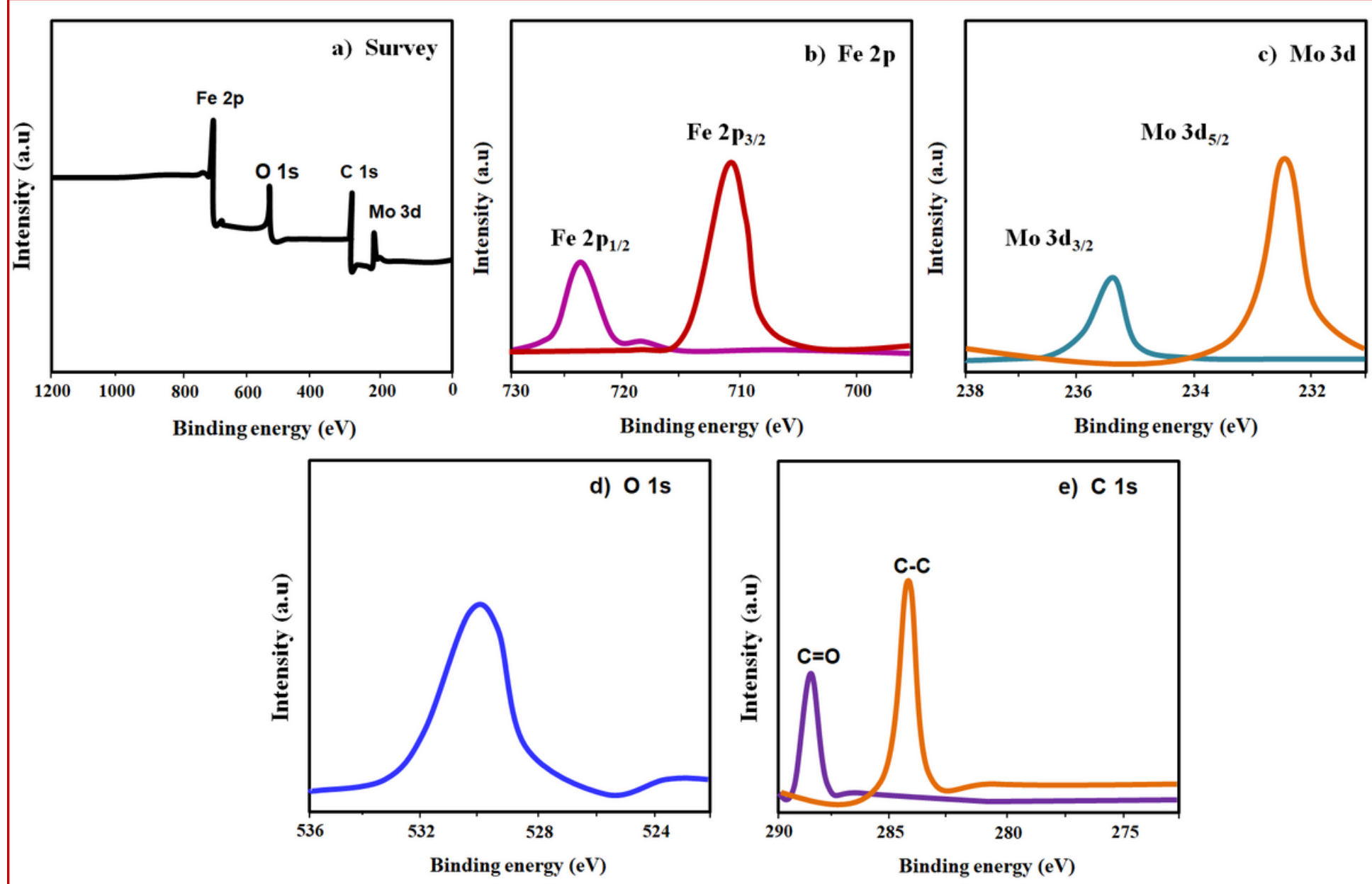
XPS spectra of APG-50 sample (a) survey; (b) F 2p; (c) Mo 3d; (d) O 1s; (e) C 1s

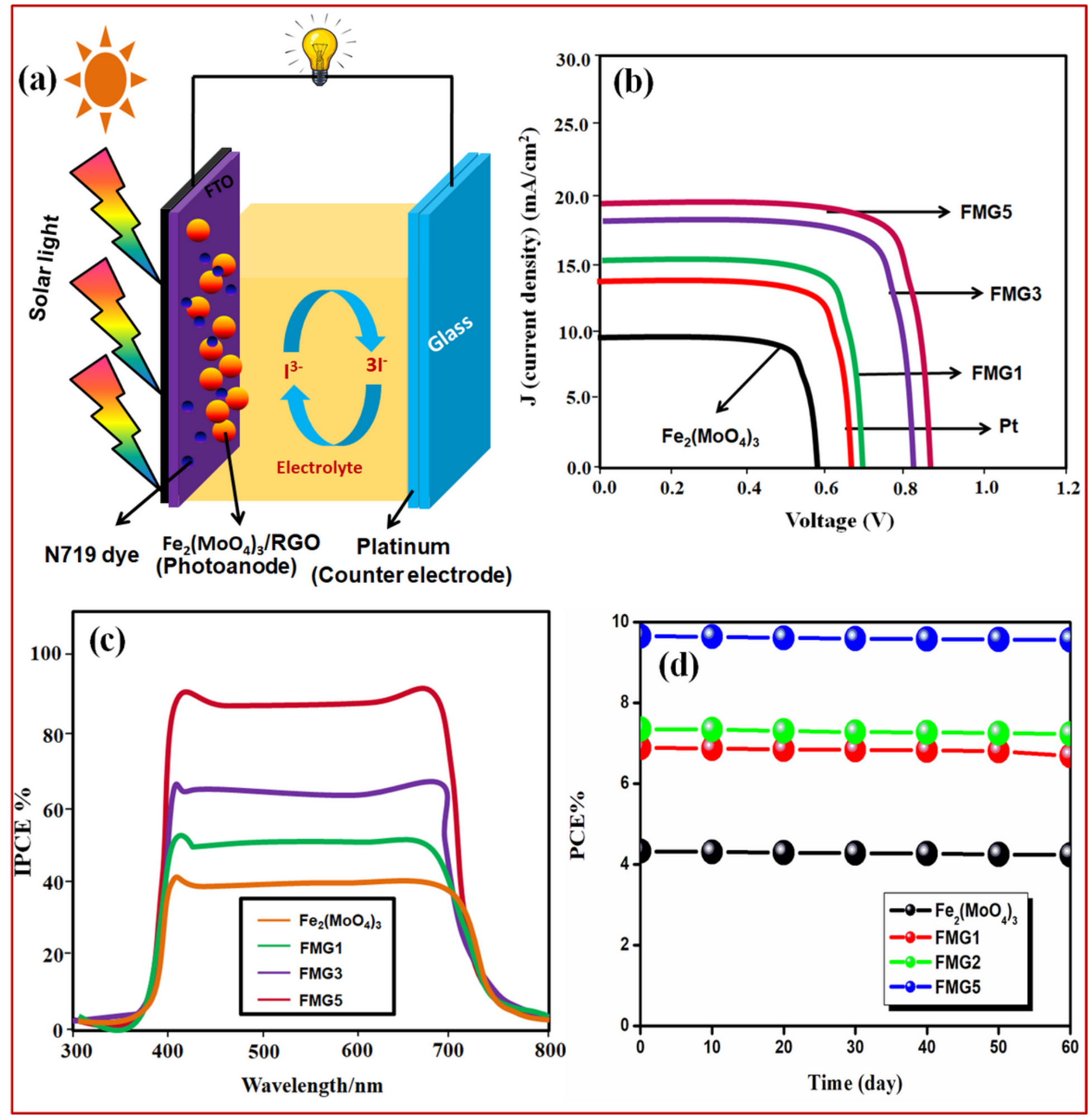

Figure 8

(a) Schematic representation of the sandwich type solar cell device; (b) J-V characteristics of all the photoelectrodes; (c) IPCE spectra; (d) stability test 


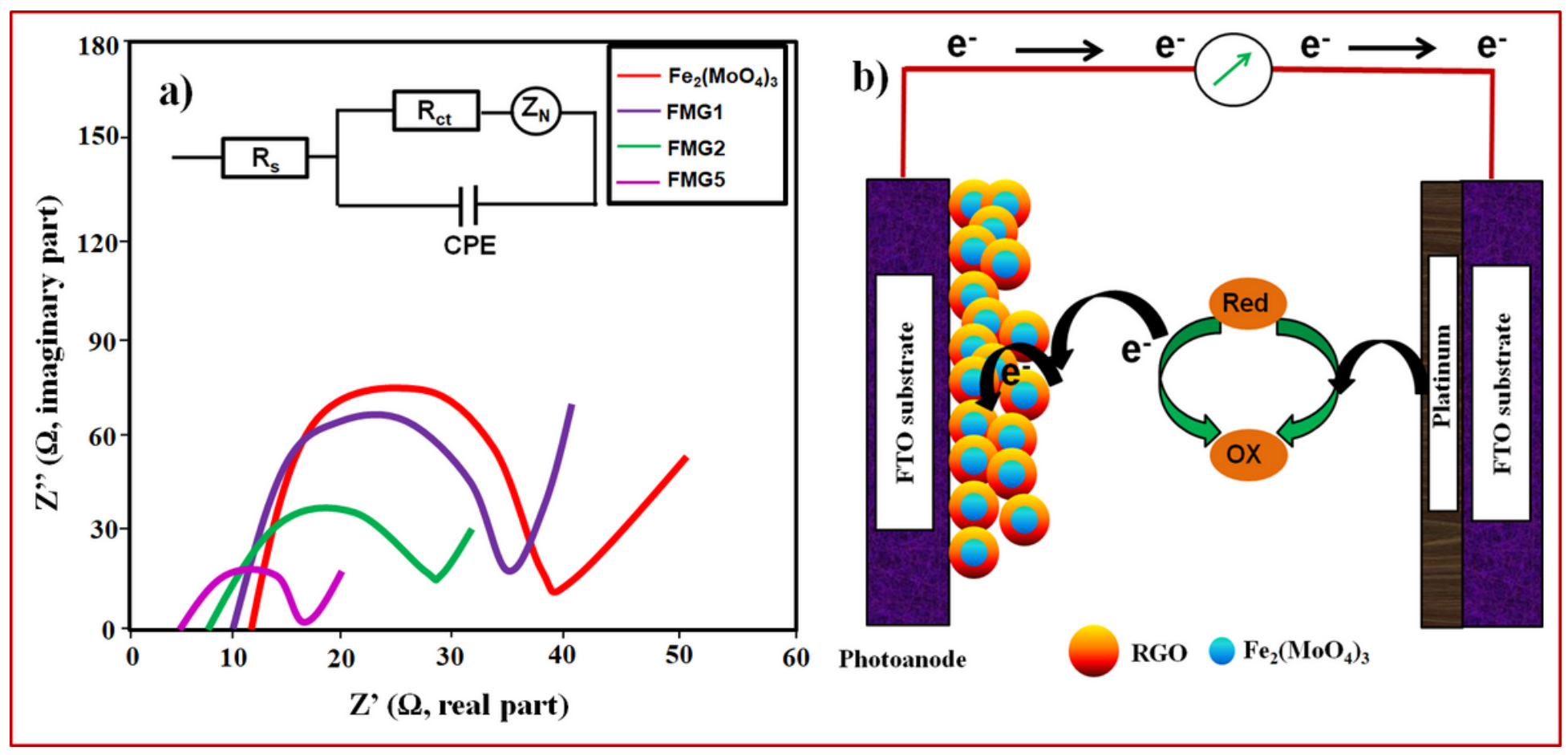

Figure 9

(a) Nyquist plot with equivalent circuit; (b) Schematic representation for photovoltaic conversion mechanism of $\mathrm{Fe} 2(\mathrm{MoO} 4) 3 / \mathrm{RGO}$ 